\title{
RESEARCH ON CONSTRUCTION OF NINGBO NATIONAL TECHNOLOGY TRANSFER DEMONSTRATION PLOT WITH CEE FEATURE
}

\author{
Hristo Angelov Hristov \\ Ningbo University of Technology, Ningbo, Zhejiang province, China \\ Wang Bo \\ Ningbo University of Technology, Ningbo, Zhejiang province, China \\ OMESTE \\ JEL Category: L24, 031, 032
}

\begin{abstract}
Ningbo is one of the first coastal open cities in China, with obvious advantages of export-oriented economy and distinct characteristics of opening and innovation, but the innovation ability of companies here was not strong. Under the new situation of scientific and technological revolution, scientific and technological innovation has increasingly become a decisive force in economic and social development, and private enterprises have strong demand for innovation transformation, so accelerating the layout of demonstration plots for scientific and technological achievements is to explore local development of science and technology. The effective mechanism and mode of achievement transformation have become a major opportunity to enhance the core competitiveness of the manufacturing industry and promote urban innovation and development. This paper studies the current situation of National Technology Transfer Demonstration Plot in Ningbo analyses the problems and countermeasures of the construction of the demonstration plot and explores the development of a special demonstration plot for the transfer and transformation of scientific and technological achievements in Central and Eastern Europe through the construction of the demonstration plot.
\end{abstract}

Keywords: innovation; scientific and technological achievements; transfer and transformation; demonstration area; Central and Eastern Europe

\section{BACKGROUND}

In October 2016, the Ministry of Science and Technology approved Ningbo as the first national demonstration plot for the transfer and

Address of the corresponding author:

Wang Bo

玤·bo305@hotmail.com transformation of scientific and technological achievements. Following the first pilot demonstration city of "Made in China 2025", Ningbo once again shouldered the national mission. In recent years, relying on the comparatively developed private economy and other basic advantages, Ningbo has formed a cooperative development mechanism with enterprises as the main body, government 
guidance, market-oriented operation and diversified capital combination around the construction of demonstration plots, which supports the economic and social development. (Ma, 2017)

Promotion of the transfer and transformation of scientific and technological achievements is an important task of implementing an innovationdriven development strategy and a key link to strengthen the close integration of science and technology with the economy. It is of great significance for promoting structural reform, especially supply-side structural reform, supporting economic transformation and upgrading and industrial restructuring, promoting mass entrepreneurship and innovation, and building a new engine of economic development.

\section{CONSTRUCTION STATUS OF NATIONAL TECHNOLOGY TRANSFER DEMONSTRATION PLOT IN NINGBO}

The construction of Ningbo National Technology Transfer Demonstration Plot focuses on stimulating the vitality of private economy, giving full play to the supporting role of transformation of scientific and technological achievements in the innovation and development of industries and enterprises, and striving for new experiences and breakthroughs in promoting the transfer and transformation of scientific and technological achievements by the main body of enterprises. Ningbo Municipal Party Committee and Municipal Government will promote the transformation of scientific and technological achievements as an important grasp in implementing the strategy of innovation-driven development, promulgated the "Ningbo City Construction of National Science and Technology Achievement Transfer and Transfer Demonstration Plot Implementation Plan". They will first try to promote the transformation of scientific and technological achievements by the enterprise main body. Then the transformation of scientific and technological achievements will be done by private capital investment, and the transformation of scientific and technological achievements to promote the cultivation of new industries the transformation mechanism and mode of scientific and technological achievements with local characteristics.

\subsection{Technology transfer market flourishing}

In recent years, through innovative science and technology policies, Ningbo has vigorously built a grid technology market with multi-level action, collaborative services, online and offline, supported and nurtured professional market operators, trained certification technology brokers, made special subsidies for the transformation of scientific and technological achievements, technology transactions and patent industrialization, and organized enterprises and colleges and universities to participate in bidding auctions and fruit docking meetings for scientific and technological achievements. Ningbo city has undertaken diversified initiatives such as innovation challenge contest to accelerate the transformation of scientific and technological innovation resources into Ningbo city agglomeration. In 2017, Ningbo's technology market continued to be active, with the annual turnover of technology contracts breaking through 10 billion yuan for the first time, an increase of $52.1 \%$ over the same period last year. In the whole year, 3073 technologies were absorbed, with a turnover value of 7.57 billion yuan, of which 1328 technologies were absorbed from outside Zhejiang Province, with a turnover value of 5.71 billion yuan; 2047 technologies were exported, with a turnover value of 2.46 billion yuan. The volume of export and absorption transactions increased by $62.0 \%$ and $28.0 \%$ respectively over the same period of last year. According to Zhejiang Science and Technology Department's "Zhejiang Science and Technology Achievement Conversion Index 2017", in 2017, Ningbo Technology Innovation Achievement Conversion Index is 263.5 , second only to Hangzhou, ranking the first line in the province.

$\begin{array}{r}\text { Table } 1 \\
\text { Transaction Volume of Ningbo } \\
\text { Technology Contract in } 2016 \text { and } 2017 \\
\text { Unit: Item, } 100 \text { million yuan }\end{array}$
\begin{tabular}{|c|c|}
\hline Year & Technical Transaction Volume \\
\hline 2016 & 65.96 \\
\hline 2017 & 100 \\
\hline
\end{tabular}

\subsection{Technology transfer platforms emerge in large numbers}

With the remarkable improvement of Ningbo's technology market scale, Ningbo's technology 
transfer platforms have emerged and shown a vigorous development trend. In 2017, Ningbo has gathered more than 500 teams of technical brokers, more than 40 technology intermediaries, and nearly 10 specialized technology transfer services. Among them, there are many international technology transfer platforms and service institutions for CEE countries, such as the Ningbo University of Technology "The Central and Eastern European Talent Initiative of Ningbo", Ningbo Silk Road Science and Technology Exchange Services Co., Ltd. In addition, more than 50 industrial technology research institutes, such as Ningbo Institute of Materials Technology \& Engineering, Chinese Academy of Sciences, Ningbo International Institute of Materials Genetics Engineering and Ningbo Intelligent Manufacturing Industry Research Institute, have built a number of platform carriers, such as pilot experimental workshops and pilot customercreating platforms. These platform carriers closely meet the needs of Ningbo's innovation and development, carry out major key technology research, and form a number of high-level scientific and technological achievements, laying the foundation for the transfer and transformation of high-quality achievements.

\subsection{The constant improvement of the business incubation system}

By exploring innovative investment operating management system, prizing angel investors and private capital, a perfect start-ups incubation mechanism which combines "Professional Incubation", "Venture Tutoring" and "Angel Investment" will be established. Besides, completing inclusive supporting policy for entrepreneurship carriers, offering a certain amount of financial aids according to incubation service performance and improvements in other forms are all necessary for continually forming professional venture incubation system. In 2017, Ningbo has built over 10 professional incubation machines in accumulative terms. Moreover, innovation and industrialization has been connected seamlessly in forming a pre-hatching mechanism for scientific and technological achievements' research, development and Chinese style transformation, encouraging and supporting venture carriers like investors and leading companies in the industry to build Chinese experimental plants, Chinese creator platforms and providing completed and specialized services such as research and development design technology incubation 、 engineering curing Chinese style transformation. Beyond 50 industrial technology research institutes have been funded with the help of a certain expenditure and awarding policy. For instance, Ningbo Bioindustry Innovation Center has already settled 23 projects since it was prepared to construct. Also, Ningbo Institute of Technology, Zhejiang University established 23 Chinese research and development centers in line with understudied items. 13 firms have already been incubated and totally 60 companies were graduated in Dental laboratories set up by Ningbo Runyes. (Ningbo science and technology bureau, 2016)

\section{EXISTING ISSUES IN CONSTRUCTING NINGBO
DEMONSTRATION PLOT}

In recent years, Ningbo has gained some exploits in the construction of "National Demonstration Plot for Transfer and Transformation of Scientific and Technological Achievements", but compared with Hangzhou and Nanjing, the overall strength of Ningbo is still weak. Problems such as the imperfect development of the market principal part, the low degree of specialization of technology transfer agencies, fewer high-end service modes and the shortage of high-quality technical brokers also exist.

\subsection{Inadequate protection institutional mechanism}

Ningbo is one of the first "National Demonstration Plots for Transfer and Transformation of Scientific and Technological Achievements". In recent years, the Municipal Party Committee and Municipal Government have been paying much attention to the construction and development of demonstration plots. This leads to the major progress both in the size and quality benefits of the transfer of technological achievements. However, compared with Hangzhou and Nanjing, the development of transfer and transformation of scientific and technological achievements in Ningbo is still lagging behind both in terms of output technology and in terms of absorption technology. Although the scale of science and technology transfer market in Ningbo is constantly 
enlarging year by year, issues like flimsy design and R\&D capability, a loose bond of industry, University and research center, and lagging of science and technology financial services are still significant shortcomings.

Table 3-1 Comparison of Technological Flow among Ningbo, Nanjing, and Hangzhou in 2017

Unit: Item, 100 million RMB

\begin{tabular}{|l|r|r|r|r|r|c|}
\hline \multirow{2}{*}{ Area } & \multicolumn{3}{|l|}{ Export Technique } & \multicolumn{3}{|l|}{ Absorption technique } \\
\cline { 2 - 7 } & $\begin{array}{c}\text { Number of } \\
\text { terms }\end{array}$ & Turnover & Ranking & $\begin{array}{c}\text { Number of } \\
\text { terms }\end{array}$ & Turnover & Ranking \\
\hline Ningbo & 2047 & 24.60 & 3 & 3073 & 75.70 & 3 \\
\hline Hangzhou & 8451 & 121.63 & 2 & 7613 & 134.13 & 2 \\
\hline Nanjing & 21036 & 284.75 & 1 & 11135 & 263.13 & 1 \\
\hline
\end{tabular}

\subsection{Weak understanding of the importance of technology transfer services in enterprises}

The survey indicates that production companies did not have any expenditure on science and technology intermediary services in a year take up $84 \%$, and those agree that the demand for science and technology intermediary services is not urgent occupy $50 \%$, and $38 \%$ of them regard science and technology intermediary services as dispensable enterprises. What can be concluded is that under the condition of the modern market economy, companies lack a strong sense of technological innovation and do not have strong desires for technological innovation services such as technology transfer, which to some extent inhibits or hinders the development of technology transfer industry. (Chen, 2018)

\subsection{Unfinished construction technical brokers team}

The technical broker is a kind of high-quality compound talent who not only knows technology and market but also management and law. At present, the Ningbo technology achievements transformation and other scientific and technological service institutions are rather small in size and low in professional service level. It is rather difficult to attract high-quality talent gathering. Therefore, in the market competition, the lag of talent team construction leads to the low level of service of Ningbo science and technology service institutions, the single method and means of service, and the weak of in-depth professional competence. This also results in the inability of meeting the comprehensive needs of high-end customers and then to a certain extent, those institutions fail in being widely recognized by society and enterprises. (Chen, 2018)

\subsection{The strength of the technology transfer platform needs to be enhanced}

Technology transfer service institutions in developed countries are highly specialized, informationized and networked, institutions adhering to the concept of multi-win, form a network alliance with complementary advantages and resource sharing, through mergers and regroup to become bigger and stronger. Compared with technology transfer service institutions in developed countries, the scale of technology transfer service institutions and platforms in Ningbo is still very small, the business positioning is not clear, the professional level is not high, the service characteristics are not prominent, the service standards and industry norms are not clear, the core competitive advantage is not obvious, the network cooperation mechanism between institutions is not perfect, which is difficult to form economies of scale.

\section{SUGGESTIONS FOR THE CONSTRUCTION OF DEMONSTRATION PLOT WITH CEE FEATURE IN NINGBO}

As an important node city of the "One Belt And One Road" strategy, Ningbo will accelerate the international scientific and technological cooperation with CEECs, build a China-CEEC scientific and technological achievements transfer platform, and make full use of domestic and foreign "two resources and two markets, especially for Slovenia, Croatia, Czech Republic 
and other developed countries and regions in central and eastern Europe, carry out the transfer, transformation and industrialization of international advanced technological achievements, and promote the construction of Ningbo "national demonstration plot for the transfer and transformation of scientific and technological achievements" with the characteristics of CEE, to carry out the transfer, transformation and industrialization of international advanced technological achievements, and promote the building of a national demonstration plot for the transfer and transformation of scientific and technological achievements in Ningbo with CEE characteristics. (Zhang, 2016)

\subsection{Promote the establishment of offshore incubators in CEE}

Set up offshore incubators in CEEC, and lead the talent to enter and "transplant with the soil", which means incubate the technology projects from CEEC overseas and transplant them to Ningbo when matured, and form the basic operation mode of projects solicitation, introduce the incubation services and team transplantation with the soil and build a one-stop service system from overseas to domestic incubation, introduction and settlement. By pooling the innovative resources of CEEC, we will build a platform for introducing and transforming overseas advanced technological achievements. Incubator uses marketing operation mode, give full play to the project of science and technology information resources advantages of CEEC, formed with international scientific and technological cooperation and hatching experience of domestic and foreign professional team, has a clear hatching, technical research and development and industrialization, the introduction, and other functions and conditions of fixed place, build system of project incubation, etc. The incubator has established a close partnership with local science and technology management institutions, enterprises, scientific research institutes and universities in central and eastern European countries and established a fixed team of high-level overseas experts. Every year for Ningbo city to introduce high - tech projects in CEE, regularly organizes a group involved in Ningbo city in central and eastern Europe promotion of scientific and technological achievements, and release Ningbo related technology project demand information to central and eastern European countries, help enterprises or scientific research institutes in Ningbo have access to market and innovation resources in CEE, and assist to carry out the marketing and technology docking activities. (Fan, 2018)

\subsection{Jointly establish industrial technology research institutes with CEE countries}

Supporting Ningbo enterprises in joining hands with well-known scientific research institutions in CEE to build a number of new industrial technology research institutes in accordance with the model of "scientific research + industry + capital". As a new organizational form emerging in the system of scientific and technological innovation, the industrial technology research institute has realized the benign interactive development among universities, enterprises, markets, and governments through market operation and achieved remarkable results in promoting the transformation of scientific and technological achievements.

At present, Ningbo has platforms, such as Ningbo Zhongxing new material research institute of $C E E$, Chinese research center for materials studies at the Academy of Sciences of Ukraine, ChinaUkraine New Material Industry Technology Research Institute, Central and Eastern European Talent Initiative of Ningbo, that have provided scientific and technological exchange services for CEEC, but in terms of the quantity and quality of industrial technologies in CEE countries, the research institutes are still in a state of improvement and enhancement, and the desired effect and scale are yet to be fully realized. We will increase policy research and support for the CEEC industrial technology research institutes, and at the same time strengthen guidance and services for the development of the CEEC industrial technology research institutes, so as to create a favorable environment for their long-term development and performance, and vigorously promote the transformation and industrialization of scientific and technological achievements. 


\subsection{Exploring methods to establishing an innovative model for technology transfer in CEE}

In recent years, with the deepening exchanges and cooperation between Ningbo and CEE countries, Ningbo has gradually established good cooperative relations with CEE universities and research institutes. Different from China, most universities and science academies in CEE have special technology transfer offices with professional personnel in charge of technology transfer and rich experience in technology transfer. With the further implementation of the One Belt One Road strategy and the huge potential market in China, CEE countries are very optimistic about the prospects for international scientific and technological cooperation with China. Therefore, Ningbo technology transfer service institutions are encouraged to establish a platform for the transfer and transformation of scientific and technological achievements in central and eastern Europe, explore the establishment of an innovation model for the transfer and transformation of scientific and technological achievements in central and eastern Europe, and exchange and learn from their experience in transnational transfer and transformation of scientific and technological achievements through cooperation with technology transfer centers of renowned universities and colleges in central and eastern Europe. At the same time, by the establishment of a long-term cooperation mechanism based on international technology transfer business, and by participating in activities such as roadshow and docking of CEE projects of the advanced technology industry capital matchmaking meeting of CEE scientific and technological achievements promotion conferences, the two sides accelerate the docking and exchange of technology projects in fields such as new generation of information technology, intelligent manufacturing and new materials, to select and introduce mature projects or technologies from universities and local innovative small and medium enterprises, incubators and university science parks in CEE. By seeking government funds and industrial funds in China, the two sides promote the industrialization of projects. This will not only speed up the transfer and transformation of technological achievements in CEE but also promote the in-depth integration of science and technology with the local economy of Ningbo, thus increase the capacity of science and technology to serve local economic development.

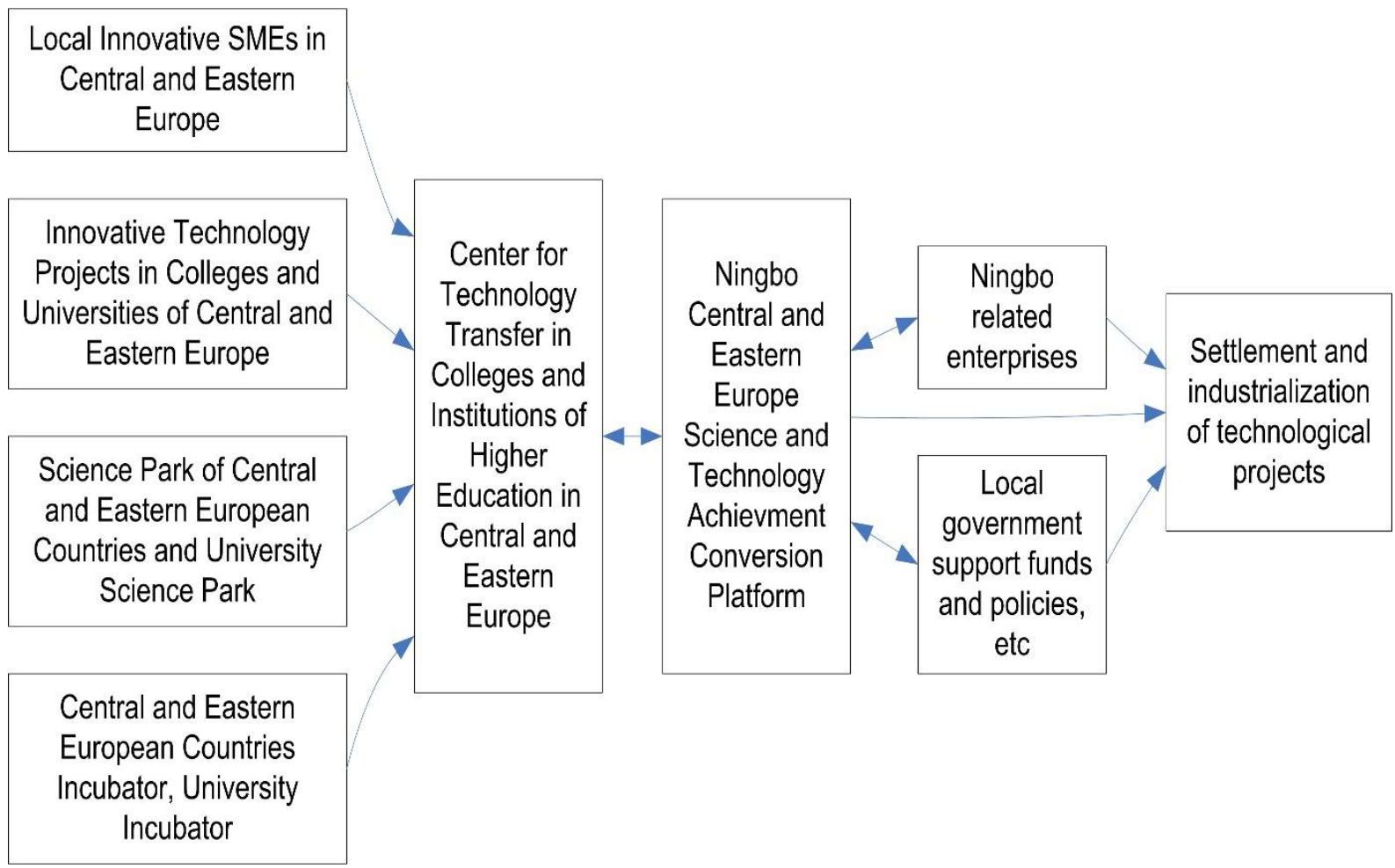

Figure 1: Transfer Model of Scientific and Technological Achievements in CEE 


\subsection{Strengthening cooperation with demonstration plots in neighboring regions}

Strengthen cooperation and linkage with Zhejiang, southern Jiangsu, Shanghai and other national demonstration plots for the transfer and transformation of scientific and technological achievements and draw lessons from their reform and innovation practice in construction layout and development mode to combine the reality of Ningbo to create comparative advantages such as technology transfer policies. Centering on the technological needs of enterprises in the Yangtze river delta region, the resources of collaborative innovation network in the Yangtze river delta region are utilized to connect the scientific and technological achievements, capital talents and other resources needed by enterprises to promote innovation and cooperation within the scope of the Yangtze river delta region. ( $\mathrm{Li}, 2004)$

\section{CONCLUSION}

In the strategic background of One Belt and One Road, science and technology cooperation between China and CEE is increasingly close, and most of science and technology innovation ability in CEE has a high place in the world. Building a National Demonstration Plot for the transfer and transformation of scientific and technological achievements in Ningbo with CEE characteristics is of great significance to promoting the transfer and transformation of innovative resources and technologies in CEE to China.

The establishment of national level demonstration plot for the transfer and transformation of scientific and technological achievements transfer in Ningbo, not only means to further promote the transfer and transformation of scientific and technological achievements transformation. At the same time, through the construction of a demonstration plot of Ningbo, the spillover and demonstration driving effect will be realized, the implementation of the national policies and regulations on the transformation of scientific and technological achievements will be promoted, the environment for the transformation of scientific and technological achievements and innovation and entrepreneurship will be optimized, and local innovation-driven development will be promoted. Carrying out pilot demonstration tasks will help improve the policy environment for the transformation of scientific and technological achievements in the region, enhance regional innovation capacity, and play an exemplary role in various aspects to explore replicable and extendable experiences and models, so as to provide support for the formulation of national policies. Ningbo demonstration plot will activate private economy as the core, play to the transformation of scientific and technological achievements for the development of the industry and the enterprise innovation support role, to explore the scientific and technological innovation resources, weak urban path and the mode of transformation of scientific and technological achievements, for the enterprise subject to promote transformation of scientific and technological achievements, the folk capital investment of science and technology achievements transformation and transformation of scientific and technological achievements to promote the emerging industries such as a breakthrough, form a group of practical work initially try measures.

\section{Acknowledgment}

The authors gratefully acknowledge the support of K. C. Wong Education, Hong Kong.

\section{WORKS CITED}

Ma, R. (2017). Suggestions on increasing support for the construction of demonstration plots for the transfer and transformation of scientific and technological achievements, China's science and technology industry, 03, 34-34 
Ningbo science and technology bureau. (2016). National science and technology achievements transfer and transformation demonstration plot why flowers fall in Ningbo, Ningbo communication, 21, 21-22

Chen, S. (2018). The causes and countermeasures of the difficulty in the transfer and transformation of China's current scientific and technological achievements, Technological economy market, 10,115-116

Zhang, S. (2016). China has launched the construction of a national demonstration plot for the transfer and transformation of scientific and technological achievements, Functional material information, 05, 23-23

Fan, Z. (2018). The strategic choice to improve the conversion rate and success rate of scientific and technological achievements, Journal of Shanxi normal university (social science edition), 05, 22-29

$\mathrm{Li}, \mathrm{Z}$. (2004). Why is it difficult to transform scientific and technological achievements, Qiushi, (03), 5.

Received for publication: $\quad$ 03.05.2019

Revision received: $\quad 16.05 .2019$

Accepted for publication: $\quad 10.07 .2019$

\section{How to cite this article?}

Style - APA Sixth Edition:

Hristov, H. A., \& Bo, W. (2019, July 15). Research on Construction of Ningbo National Technology Transfer Demonstration Plot with CEE feature. (Z. Cekerevac, Ed.) MEST Journal, 7(2), 41-48. doi:10.12709/mest.07.07.02.05

Style - Chicago Sixteenth Edition:

Hristov, Hristo Angelov, and Wang Bo. 2019. "Research on Construction of Ningbo National Technology Transfer Demonstration Plot with CEE feature." Edited by Zoran Cekerevac. MEST Journal (MESTE) 7 (2): 41-48. doi:10.12709/mest.07.07.02.05.

Style - GOST Name Sort:

Hristov Hristo Angelov and Bo Wang Research on Construction of Ningbo National Technology Transfer Demonstration Plot with CEE feature [Journal] // MEST Journal / ed. Cekerevac Zoran. Belgrade - Toronto : MESTE, July 15, 2019. - 2 : Vol. 7. - pp. 41-48.

Style - Harvard Anglia:

Hristov, H. A. \& Bo, W., 2019. Research on Construction of Ningbo National Technology Transfer Demonstration Plot with CEE feature. MEST Journal, 15 July, 7(2), pp. 41-48.

Style - ISO 690 Numerical Reference:

Research on Construction of Ningbo National Technology Transfer Demonstration Plot with CEE feature. Hristov, Hristo Angelov and Bo, Wang. [ed.] Zoran Cekerevac. 2, Belgrade - Toronto: MESTE, July 15, 2019, MEST Journal, Vol. 7, pp. 41-48. 